\title{
TOLERANCE TO IRRIGATION WATER SALINITY IN PHYSALIS PLANTS: PRODUCTIVE ASPECTS
}

\author{
TOLERÂNCIA À SALINIDADE DA ÁGUA DE IRRIGAÇÃO EM PLANTAS DE \\ FISÁLIS: ASPECTOS PRODUTIVOS
}

\author{
Joseano Graciliano da SILVA ${ }^{1 *}$; Kilson Pinheiro LOPES ${ }^{2}$; Odair Honorato de OLIVEIRA ${ }^{3}$; \\ Marília Hortência Batista da Silva RODRIGUES ${ }^{4}$; Francisco Jean da Silva PAIVA ${ }^{5}$ \\ 1. Postgraduate program in seed science and technology, Federal University of Pelotas, Rio Grande do Sul, Brazil. \\ joseano_agronomo@outlook.com; 2. Professor: Agri-Food Science and Technology Center, Pombal, PB, Brazil; 3. Postgraduate \\ program in agronomy, Federal University of Grande Dourados, MS, Brazil;4. Postgraduate program in agronomy, Federal University of \\ Paraiba, Areia, PB, Brazil; 5. Postgraduate program in agricultural engineering, Federal University of Campina Grande, Campina \\ Grande, PB, Brazil.
}

\begin{abstract}
The cultivation of non-traditional fruits has gained ground in the horticulture sector, but which, in certain situations, are plants that require previous studies related to soil adaptability, climate, and irrigation water quality. In this sense, this work aimed to evaluate the effects of irrigation water salinity on Physalis peruviana L. (fisális) plants in the different growth phases. The experimental area was installed on the premises of the Federal University of Campina Grande, adopting a casualized block design, with four saline levels of irrigation water $\left(0.3 ; 1.2 ; 2.1\right.$ and $\left.3.0 \mathrm{dS} \mathrm{m}^{-1}\right)$ and five repetitions per treatment. The variables analyzed were: stem diameter, plant height and number of leaves every 15 days, leaf area at 55 days after transplanting, number of side branches, number of flower buds, number of flowers, average fruit weight, polar diameter, and equatorial diameter of fruits, number of fruits per plant and productivity. According to the results, the plants were tolerant to saline levels of irrigation water of up to $3.0 \mathrm{dS} \mathrm{m}^{-1}$, without prejudice to the phenological and productive characteristics of the crop. The unitary increase in the salinity of the irrigation water did not result in damage to the physiological characteristics of the plants until the 60 days of transplanting.
\end{abstract}

KEYWORDS: Electric conductivity. Physalis peruviana L. Productivity. Semiarid.

\section{INTRODUCTION}

Fisális (Physalis peruviana L., Solanaceae), also known as camapú or juá-de-capote, can grow up to $1.5 \mathrm{~m}$ in height, is allogamous, mainly propagated by seeds, but also asexual (LOPEZ ACOSTA et al., 2008; FISCHER; ALMANZAMERCHÁN; MIRANDA, 2014; TANAN, 2015). Originating in the Andes region, more specifically in Bolivia, where approximately $50 \%$ of its production is exported. It also sells throughout South America and Spain, which bought a large part of the production of fisális (PUENTE et al., 2011).

As described by Ramírez et al. (2013), fisális has an indeterminate growth habit, similar to peppers. This is because, during the development of the meristem, new branches and lateral shoots appear, the leaves are heart-shaped and, then, the first flower buds appear at 70 to 80 days after germination, and the anthesis can last around 20 days, from there, two other branches grow forming a bifurcation. The complete maturation of fisális fruits usually occurs after 100 days of cultivation, when the seeds are already fully developed, with physiological, biochemical, and structural changes that may indicate the ideal point of maturation (BARROSO, 2015).

In Brazil, studies with the phenology of fisális are still incipient, with some studies with the species carried out mainly in southern Brazil (LIMA et al., 2009; MUNIZ et al., 2015). An important factor when characterizing the productive development of certain plants is the fact that it can plan planting and harvesting in favorable times and obtain a greater economic return since fisális has shown high acceptance in the horticultural sector.

In irrigation management, the quality, lack, or excess of water can cause problems in the development and productivity of the species. The volume of water supplied to the plants, mainly during flowering and fruiting, according to Silva et al. (2015), directly influences gas exchange and fluorescence in eggplant plants (Solanum melongena $\mathrm{L}$.), so that its excess can affect aeration in the root zone and leaching of nutrients, while its lack can inhibit the growth of the plant and affect several productive aspects, including productivity. 
Tolerance to irrigation...

Considering the semiarid condition of the Brazilian Northeast where the evaporation is greater than the volume of rainfall and the geological formation of the soils occurs from the crystalline, there is a predominance of salts on the surface of the soils, as well in the water table (SILVA et al., 2011), forcing producers to use water from deep wells, salinizing the soil and preventing the cultivation of most crops in the region. Therefore, the quantity and quality of irrigation water can cause significant stresses on the plant, influencing the distribution of water in the different parts that compose it.

Regarding the presence of salts in the irrigation water, Ianckievicz et al. (2013) report that fisális plants, submitted to fertilization with saline concentrations of nutrients corresponding to $3.0 \mathrm{dS}$ $\mathrm{m}^{-1}$, presented a greater fresh weight of the fruits. Campos and Cavalcante (2009) observed that sweet pepper (Capsicum annuum L., Solanaceae) tolerates up to $1.88 \mathrm{dS} \mathrm{m}^{-1}$ of salts in irrigation water and bovine biofertilizer as a saline attenuator. According to Dias and Blanco (2010), in saline conditions, both plant growth and production can be reduced, which
SILVA, J. G. et al.

can be attributed to the effect of toxic ions (chlorine, sodium, and boron) and osmotic stress.

Given the above, aimed to evaluate the effects of irrigation water salinity on fisális plants in the different growth phases.

\section{MATERIAL AND METHODS}

The work was developed in the Laboratory of Analysis of Seeds and Seedlings and in the greenhouse of the Center for Science and Agri-Food Technology at the Federal University of Campina Grande, in Pombal - PB, and in a protected environment on the experimental farm, in São Domingos - PB. The geographical location of the city of São Domingos is at $6^{\circ} 48^{\prime} 41.7$ "S $37^{\circ}$ $56^{\prime} 13.8^{\prime \prime} \mathrm{W}$ and an altitude of $190 \mathrm{~m}$, with a semiarid tropical climate, with summer rains from November to March (SILVA et al., 2011) low cloudiness, strong sunlight and high evaporation rates. The climatological data collected during the experiment are shown in Figure 1.

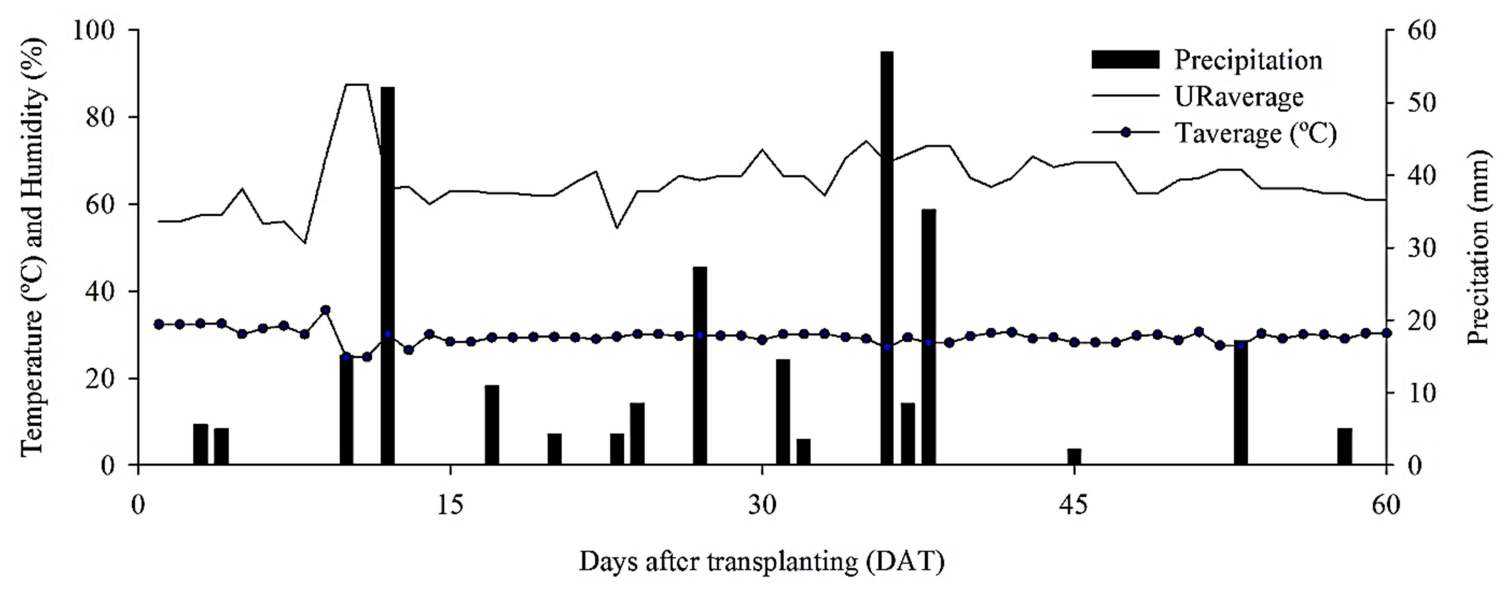

Figure 1. Average values for temperature $\left({ }^{\circ} \mathrm{C}\right)$ and relative humidity $(\%)$ and rainfall data during the experiment with Physalis peruviana L. plants under different saline levels of irrigation water, in a protected environment.

UFCG, Pombal, PB, June of 2020.

The seeds used came from fruits produced in Colombia and purchased in specialized horticultural from the city of João Pessoa - PB, with an average weight of $4.91 \mathrm{~g}$, which were cut in half with the aid of a scalpel, and the seeds washed under running water in a fine-mesh sieve for the complete removal of the pulp. Then, the seeds were allowed to dry under laboratory conditions for three days on two sheets of Germitest paper. Subsequently, they were stored in a refrigerator $( \pm 5$ ${ }^{\circ} \mathrm{C}$ ) until the tests were installed and then treated with a $2 \%$ hypochlorite for five minutes.
Sowing was carried out at $0.5 \mathrm{~cm}$ depth in polypropylene containers with a capacity of $50 \mathrm{~mL}$, filled with commercial substrate Hortiplant ${ }^{\circledR}$, whose chemical characteristics of the substrate are shown in Table 1 (Substrate for seedling production - SPM) and conditioned in a greenhouse receiving three daily irrigations with the aid of a watering can until 30 days after sowing (DAS). Then they were taken from the Agri-Food Science and Technology Center to the Experimental Farm and transplanted to plastic vessels with a capacity of $12 \mathrm{~L}$, with a hole in the base, added $200 \mathrm{~g}$ of $\mathrm{n}^{\circ} 1$ gravel and filled with 10 
$\mathrm{dm}^{3}$ of a substrate composed of soil, sand and manure in the proportions $2: 1: 1$, whose chemical and physical characteristics are shown in Table 1 (Substrate for cultivation - SC).

Table 1. The chemical and physical composition of substrates used in the production of seedlings (PS) and in the cultivation (SC) of Physalis peruviana L. under different levels of irrigation water salinity; and chemical composition of irrigation water used in the cultivation of Physalis peruviana L. under different levels of irrigation water salinity.

\begin{tabular}{|c|c|c|c|c|c|c|c|c|c|c|c|c|}
\hline \multicolumn{13}{|c|}{ Chemical and physical composition of substrates } \\
\hline & \multirow{2}{*}{\multicolumn{2}{|c|}{ Water $(1: 2.5)$}} & & \multirow{2}{*}{$\begin{array}{l}\mathrm{P} \\
---\mathrm{mg} \mathrm{dm}\end{array}$} & ${\mathrm{S}-\mathrm{SO}_{4}{ }^{2}}^{2}$ & $\mathrm{~K}^{+}$ & $\mathrm{Na}^{+}$ & \multicolumn{2}{|c|}{$\mathrm{H}^{+}+\mathrm{Al}^{3+}$} & $\mathrm{Al}^{3+}$ & & $\mathrm{Ca}^{2+}$ \\
\hline & & & & & $1^{-3}---$ & --- & $---\cdot$ & $-\mathrm{cmol}_{\mathrm{c}}$ & & & & \\
\hline PS & \multicolumn{2}{|l|}{5.5} & & 257.30 & - & 2.00 & 0.43 & 8.57 & & 0.05 & & 2.69 \\
\hline $\mathrm{SC}$ & \multicolumn{2}{|l|}{7.4} & & 733.39 & - & 2.73 & 1.20 & 0.00 & & 0.00 & & 1.23 \\
\hline & \multicolumn{2}{|c|}{$\mathrm{Mg}^{2+}$} & & SB & CEC & O.M & Sand & Silt & & Clay & & \multirow{2}{*}{ Textural class } \\
\hline & \multirow{2}{*}{\multicolumn{5}{|c|}{ - }} & \multicolumn{4}{|c|}{  } & & & \\
\hline PS & \multirow{2}{*}{\multicolumn{2}{|c|}{$\begin{array}{l}1.46 \\
1.09\end{array}$}} & & \multirow{2}{*}{$\begin{array}{l}3.89 \\
625\end{array}$} & 12.46 & 233.51 & 878 & 113 & & 9 & & \\
\hline $\mathrm{SC}$ & & & & & 6.25 & 10.34 & 789 & 155 & & 56 & & Frank sand \\
\hline \multicolumn{13}{|c|}{ Chemical composition of irrigation water } \\
\hline $\mathrm{ECw}$ & $\mathrm{pH}$ & $\mathrm{Ca}^{2+}$ & $\mathrm{Mg}^{2+}$ & $\mathrm{K}^{+}$ & $\mathrm{Na}^{+}$ & $\mathrm{CO}_{3}{ }^{2-}$ & $\mathrm{HCO}_{3-}$ & $\mathrm{Cl}^{-}$ & $\mathrm{SO}_{4}^{2}$ & \multirow{2}{*}{\multicolumn{2}{|c|}{$\overline{C S R}$}} & \multirow{2}{*}{ SAR } \\
\hline 0.3 & 720 & 02 & & 12 & 120 & $\frac{0.00}{0.00}$ & 215 & 160 & ר? & & & \\
\hline 1.2 & 6.33 & 3.05 & 250 & 0.67 & 3.90 & 0.00 & 6.15 & 6.20 & 0.02 & & 0.65 & 2.01 \\
\hline 2.1 & 7.38 & 2.03 & 1.47 & 0.28 & 3.07 & 0.49 & 6.23 & 10.73 & 0.15 & & 3.22 & 3.33 \\
\hline 3.0 & 8.60 & 2.75 & 1.25 & 0.05 & 4.01 & 1.48 & 10.34 & 24.40 & 0.44 & & 7.82 & 4.01 \\
\hline
\end{tabular}

UFCG, Pombal, PB, June of 2020.

P, K, Na: Extractor Mehlich 1; SB: Sum of Exchangeable Bases; H + Al: Extractor Calcium Acetate 0.5 M, pH 7,0; CEC: Cation Exchange Capacity; Al, Ca, Mg: Extractor KCl $1 \mathrm{M}$; OM.: Organic Matter - Walkley-Black. $\mathrm{Ca}^{2+}=\mathrm{Calcium} \mathrm{Mg}^{2+}=\mathrm{Magnesium}^{+} \mathrm{K}^{+}=$ potassium; $\mathrm{Na}^{+}=$Sodium; $\mathrm{CO}_{3}{ }^{2-}=$ Carbonate; $\mathrm{HCO}_{3-}=$ bicarbonate; $\mathrm{Cl}^{-}=$Chlorine; $\mathrm{SO}_{4}{ }^{2-}=$ Sulfate; $\mathrm{RSC}=$ Residual sodium carbonate; $\mathrm{SAR}=$ Sodium adsorption ratio

The soil used in the pots was collected in the $0-20 \mathrm{~cm}$ layer in the fallow area on the experimental farm where the experiment was conducted. According to EMBRAPA (2018), the soil used is a Neossolo Flúvico Ta Eutrófico (RYve). From then on, composite samples were sent to the soil analysis laboratory of the Federal University of Paraiba, Areia campus and subjected to chemical and physical analysis, to characterize soil fertility and fertilization, based on the recommendations for tomato culture (FILGUEIRA, 2003; THOMÉ; OSAKI, 2010; MUNIZ et al., 2015). As a mulch, each pot received 100 grams of crushed dry grass pomace, in order to maintain soil moisture and temperature.

The position of the cultivation line adopted in the experiment was East-West, with plants spaced $1.5 \mathrm{~m}$ between rows $\times 1.0 \mathrm{~m}$ between plants. The conduction system of the plants was in a spreader with two main branches, using three galvanized wire wires spaced $0.5 \mathrm{~m}$ from the edge of the pot, arranged longitudinally, for the correct staking of the branches (MUNIZ et al., 2011). For this purpose, formation pruning was carried out from
$0.45 \mathrm{~m}$ in height and bi-weekly sprouting of the lateral branches.

In the covering fertilization, applications of $\mathrm{MgSO}_{4} .4 \mathrm{H}_{2} \mathrm{O}$ e $\mathrm{CaSO}_{4}\left(1 \mathrm{Mol} \mathrm{L}^{-1}\right)$ at 21 and 35 days after transplantation (DAT) using $1.5 \mathrm{~mL} \mathrm{dm}^{-3}$ of soil, and two applications of mixed fertilizer containing $\mathrm{N}, \mathrm{P}, \mathrm{K}, \mathrm{Ca}$, and $\mathrm{S}(10,10,10,4$ and $11 \%$, respectively) at 28 and 42 DAT using $1.5 \mathrm{~g}$ $\mathrm{dm}^{-3}$ of soil. The water used for irrigation came from artesian wells and from the urban supply system, mixed, in order to obtain electrical conductivities $0.3 ; 1.2 ; 2.1$, and $3.0 \mathrm{dS} \mathrm{m}^{-1}$, whose chemical characteristics are shown in Table 1. However, during the first seven days after transplant, only good quality water $\left(0.3 \mathrm{dS} \mathrm{m}^{-1}\right)$ was applied for the proper establishment of the seedlings. The weekly ECw check was performed with the aid of a portable conductivity meter.

To determine the volume of water needed, the following equation was used:

$V i=\frac{\mathrm{Va}-\mathrm{V}}{1-\mathrm{LF}}$ 
Where: $\mathrm{Vi}=$ Volume to be irrigated; $\mathrm{Va}=$ Volume applied; Vd = Volume drained after 24 hours of application; $\mathrm{LF}=$ Leaching factor $(10 \%)$.

To determine the volume drained and the electrical conductivity of the drain (ECd) the samples were collected 24 hours after irrigation. For quantifying the increase in $\mathrm{ECd}$, a portable conductivity meter was used. At 120 DAT, simple soil samples were collected and formed a composite sample from each treatment to determine the electrical conductivity of the saturation extract (ECes) and $\mathrm{pH}$, according to the methodology described by Richards (1954). Based on the ECes and the $\mathrm{pH}$ of each solution, it was measured with a conductivity meter and bench, with automatic temperature correction.

Sprayings were performed with insecticide (Imidacloprid, $1 \mathrm{~g} \mathrm{~L}^{-1}$ ) and acaricide (Avermectin, $0.5 \mathrm{~mL} \mathrm{~L}^{-1}$ ) for the control of whitefly (Bemisia argentifolii) and red mite (Tetranychus urticae), respectively. Observing the beginning of anthesis, the plants were manually vibrated daily to stimulate self-pollination. From the transplant and throughout the experiment, measurements were taken of the temperature and the relative humidity of the air inside the nursery, with the aid of a thermohygrometer, and of the rainfall in the area. The growth assessments in the respective phenological phases (vegetative, flowering, and fruiting) of fisális were carried out every 15 days during the entire cultivation phase, by means of the following determinations:

Stem diameter: performed with the aid of a digital caliper one centimeter above the ground. The results were expressed in millimeters.

Average plant height: using measuring tape graduated in centimeters, measuring from the base of the plant to the apical meristem. The data expressed in centimeters per plant.

Number of leaves: the number of leaves as a function of DAT was quantified from the first leaf from the bottom to the apical meristem of the last branch. For this purpose, only those that presented a fully formed or expanded limbus and main rib with a minimum length of $3 \mathrm{~cm}$ were considered. The data expressed as the number of leaves per plant.

Number of lateral branches: Quantified during the sprouts.

Leaf area of plants: at $55 \mathrm{DAT}$, the leaf area was determined by measuring the length (C) and width (L) of all the leaves of the plants, considering as length the distance between the insertion point of the petiole in the leaf blade and the extremity opposite of the leaf, and the width, as the largest dimension perpendicular to the length axis, according to Reis et al. (2013), applying the following equation:

$$
\mathrm{LA}=\mathrm{CLf}
$$

Where: LA - leaf area, $\mathrm{m}^{2}$; and $\mathrm{C}$ - leaf length, $\mathrm{m}$; L - leaf width, $\mathrm{m}$; $\mathrm{f}$ - correction factor (0.59).

Number of flower buds and flowers: flower buds were those whose size was greater than three millimeters, visible between the branches and greenish in color; the flowers were quantified, at most, within 24 hours after anthesis, when the floral whorls were completely expanded;

Number of fruits per plant and productivity: the harvests were carried out twice a week, only when the cup had a brownish-yellow color, approximately 40 days after anthesis (BARROSO, 2015), extending until the end of the production cycle, which occurred around 115 DAT. The yield was estimated based on the number of fruits per plant and plants per hectare, taking into account the spacing adopted, according to the equation below:

Productivity $=\frac{\text { production per plant } \times 10.000 \mathrm{~m}^{2}}{\text { area occupied by plant }}$

The harvested fruits were measured for their diameter and length with the aid of a digital caliper and weighed on an analytical balance $(0.001 \mathrm{~g})$. The results were expressed in grams of fruit ${ }^{-1}$.

A randomized block design was used with five replications of three plants per treatment using water with different levels of electrical conductivity $(\mathrm{ECw})\left(0.3 ; 1.2 ; 2.1\right.$ and $\left.3.0 \mathrm{dS} \mathrm{m}^{-1}\right)$. The data obtained were subjected to analysis of variance and regression, at the level of 5\% probability, using the statistical program Sisvar 5.3 (FERREIRA, 2011).

\section{RESULTS AND DISCUSSION}

According to the climatic data of precipitation, temperature, and relative humidity (Figure 1) during the conduct of the experiment with fisális (February to June), the precipitation extended between the months of February to April, with greater intensity between mid february and march, with maximum values of up to $57 \mathrm{~mm}$ daily. Regarding the average temperatures throughout the experiment, the values remained around $29^{\circ} \mathrm{C}$ while the humidity of the air remained around $64 \%$ in the months when precipitation was more frequent, 
tending to reduce to $55 \%$ when rains stopped in the region.

The climatic phenomena that were observed during the study period corresponded to lower averages than what usually occurs in the region, as described by Silva et al. (2011) when mentioning values of up to 63 rainy days each year in the state of Paraíba and average precipitation of $129 \mathrm{~mm}$ between the months of February to May, characterizing, therefore, the passage through atypical climatic periods in the region. According to Vasconcelos et al. (2015), the success of the implanted crops depends on the regularity and amount of rainfall that falls on the cultivation areas with a direct influence on the temperature-relative humidity ratio.

The analysis of variance regarding the variables of the vegetative phase is shown in Table 3. It can be seen that there was no significant effect $(p>0.05)$ between the treatments analyzed in plants of fisális until 120 DAT. Thus, due to the absence of the effect of salinity on the plants of fisális, the data were arranged in schemes illustrating the development of the plants depending on the evaluation period.

Table 3. Summary of analysis of variance for stem diameter (SD), plant height (PH) and number of leaves (NL) from 15 to $120 \mathrm{DAT}$, leaf area (LA) at 55 DAT, and number of lateral branches (NLB) in Physalis peruviana L. plants grown under different saline levels of irrigation water, under-protected environment conditions.

\begin{tabular}{|c|c|c|c|c|c|c|}
\hline & \multirow{2}{*}{ DAT } & \multicolumn{3}{|c|}{---------- Medium square ----------- } & \multirow[b]{2}{*}{ Average } & \multirow[b]{2}{*}{ CV\% } \\
\hline & & Salinity & Block & Mistake & & \\
\hline \multirow{8}{*}{ SD } & 15 & $0.034^{\mathrm{ns}}$ & $0.216^{\mathrm{ns}}$ & 0.245 & 3.62 & 13.67 \\
\hline & 30 & $0.448^{\mathrm{ns}}$ & $0.658^{\mathrm{ns}}$ & 0.535 & 5.72 & 12.79 \\
\hline & 45 & $0.300^{\mathrm{ns}}$ & $0.500^{\mathrm{ns}}$ & 0.820 & 9.34 & 9.70 \\
\hline & 60 & $0.079^{\mathrm{ns}}$ & $0.431^{\mathrm{ns}}$ & 0.556 & 11.15 & 6.70 \\
\hline & 75 & $0.523^{\mathrm{ns}}$ & $0.541^{\mathrm{ns}}$ & 0.625 & 12.33 & 6.41 \\
\hline & 90 & $0.410^{\mathrm{ns}}$ & $0.429^{\mathrm{ns}}$ & 0.722 & 13.00 & 6.54 \\
\hline & 105 & $0.257^{\mathrm{ns}}$ & $0.499^{\mathrm{ns}}$ & 0.568 & 13.13 & 5.74 \\
\hline & 120 & $0.321^{\mathrm{ns}}$ & $0.422^{\mathrm{ns}}$ & 0.612 & 13.07 & 5.99 \\
\hline \multirow{8}{*}{ PH } & 15 & $0.402^{\mathrm{ns}}$ & $0.397^{\mathrm{ns}}$ & 1.762 & 6.33 & 20.96 \\
\hline & 30 & $5.433^{\mathrm{ns}}$ & $19.728^{\mathrm{ns}}$ & 18.516 & 19.74 & 21.74 \\
\hline & 45 & $11.446^{\mathrm{ns}}$ & $7.210^{\mathrm{ns}}$ & 37.540 & 48.36 & 12.67 \\
\hline & 60 & $10.686^{\mathrm{ns}}$ & $25.094^{\mathrm{ns}}$ & 33.336 & 73.12 & 7.90 \\
\hline & 75 & $28.730^{\mathrm{ns}}$ & $66.087^{\mathrm{ns}}$ & 43.414 & 98.29 & 6.70 \\
\hline & 90 & $119.631^{\mathrm{ns}}$ & $159.425^{\mathrm{ns}}$ & 70.367 & 119.62 & 7.01 \\
\hline & 105 & $274.681^{\mathrm{ns}}$ & $22.547^{\mathrm{ns}}$ & 81.108 & 119.98 & 7.51 \\
\hline & 120 & $180.159^{\mathrm{ns}}$ & $68.971^{\mathrm{ns}}$ & 67.575 & 119.80 & 6.86 \\
\hline \multirow{8}{*}{ NL } & 15 & $0.326^{\mathrm{ns}}$ & $0.244^{\mathrm{ns}}$ & 0.881 & 6.53 & 14.37 \\
\hline & 30 & $1.591^{\mathrm{ns}}$ & $0.798^{\mathrm{ns}}$ & 3.872 & 13.53 & 14.55 \\
\hline & 45 & $32.394^{\mathrm{ns}}$ & $88.972^{\mathrm{ns}}$ & 109.629 & 37.88 & 27.64 \\
\hline & 60 & $15.412^{\mathrm{ns}}$ & $83.126^{\mathrm{ns}}$ & 154.278 & 75.49 & 16.45 \\
\hline & 75 & $49.408^{\mathrm{ns}}$ & $56.290^{\mathrm{ns}}$ & 214.973 & 86.05 & 17.04 \\
\hline & 90 & $647.720^{\mathrm{ns}}$ & $785.644^{\mathrm{ns}}$ & 261.859 & 108.65 & 14.89 \\
\hline & 105 & $310.887^{\mathrm{ns}}$ & $204.055^{\mathrm{ns}}$ & 135.884 & 107.47 & 10.85 \\
\hline & 120 & $163.587^{\mathrm{ns}}$ & $231.371^{\mathrm{ns}}$ & 163.673 & 92.07 & 13.90 \\
\hline LA & 60 & $0.002^{\mathrm{ns}}$ & $0.001^{\mathrm{ns}}$ & 0.003 & 0.27 & 20.23 \\
\hline NLB & - & $7.440^{\mathrm{ns}}$ & $13.548^{\mathrm{ns}}$ & 8.143 & 22 & 13.16 \\
\hline DF & - & 3 & 4 & - & - & - \\
\hline
\end{tabular}

UFCG, Pombal, PB, June of 2020.

$\mathrm{ns}=$ not significant $(\mathrm{p}>0.05)$

According to Figure 2, the vegetative phase of fisális in the conditions adopted in the experiment was concluded between 32 and 45 DAT while the reproductive phase comprised the period from 32 to
120 DAT, whose harvest of ripe fruits was carried out when the chalice and the fruit had a brownishyellow color, carried out from 75 DAT, extending until the end of the experiment. 


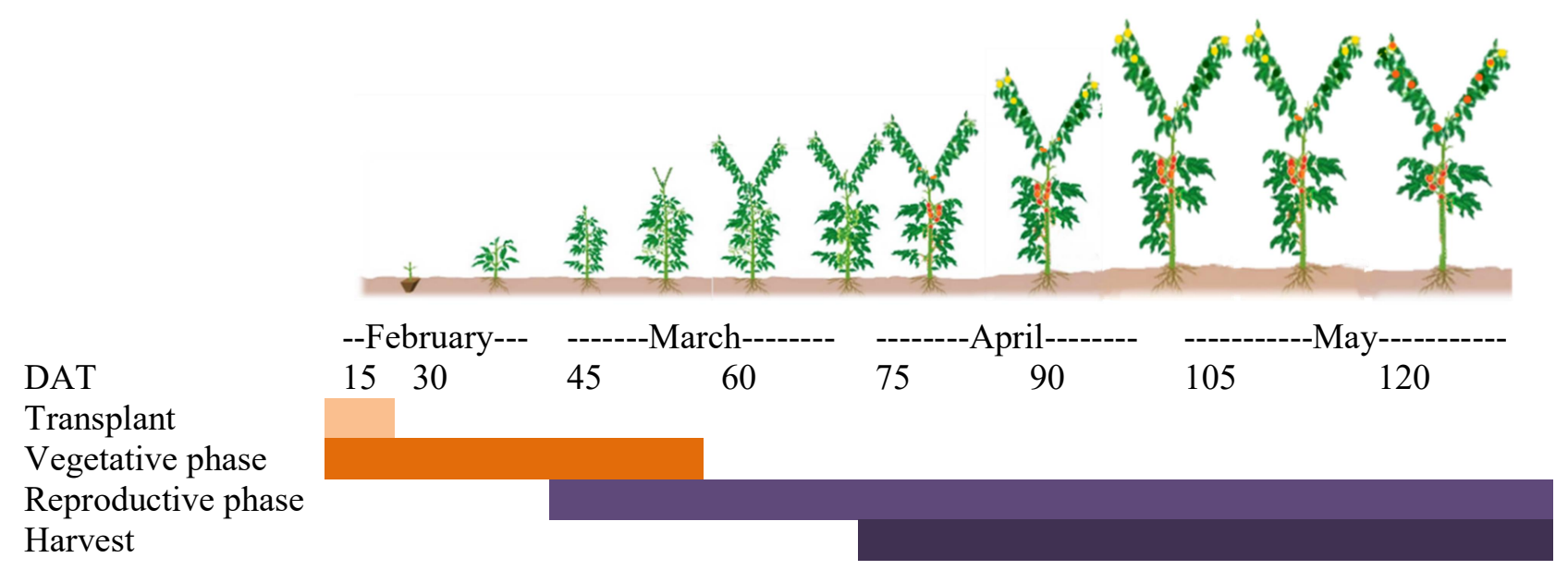

Figure 2. Phenological stages in the culture of Physalis peruviana L. under different saline levels of irrigation water, in protected environment conditions. UFCG, Pombal, PB, June of 2020.

According to Figure $3 \mathrm{~A}$, the stem diameter variable showed increasing values of $9.34 \mathrm{~mm}$ when the vegetative to reproductive phase changed at 45 DAT and a maximum value of $13.13 \mathrm{~mm}$ at 105
DAT. Unlike what was observed by Lima et al. (2015) for eggplant culture, where the unitary increase in saline levels by up to $6.0 \mathrm{dS} \mathrm{m}^{-1}$, reduced the plant diameter by $4.3 \%$ up to 120 DAT.
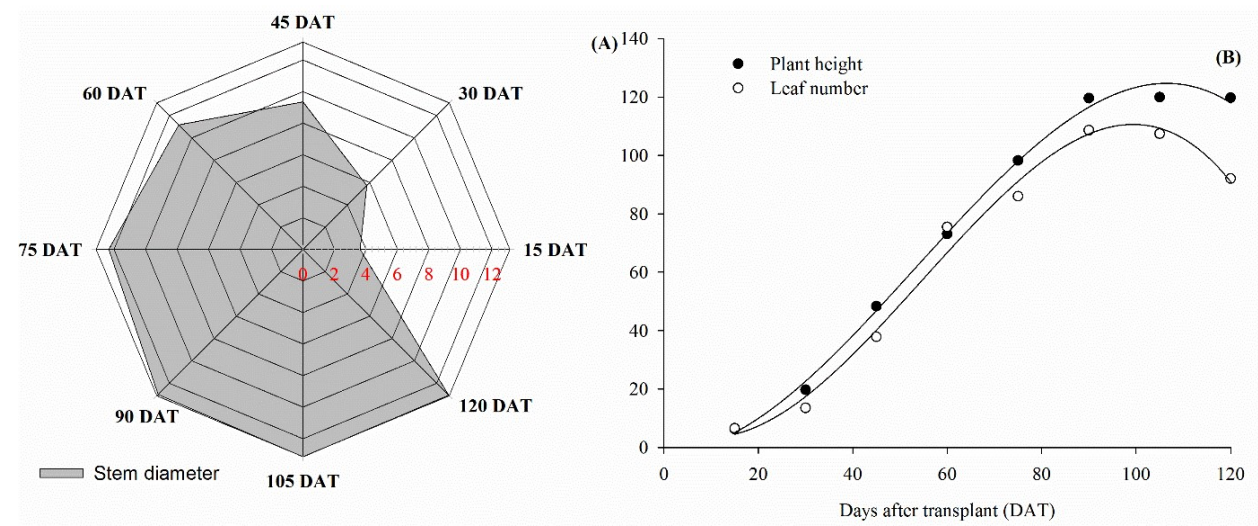

Figure 3. Stem diameter (A), plant height, and number of leaves (B) in Physalis peruviana L. plants under different saline levels of irrigation water, in protected environment conditions.

UFCG, Pombal, PB, June of 2020.

The data presented in Figure 3B demonstrate the approximate moment when the plants reached up to $1.2 \mathrm{~m}$ in height at $120 \mathrm{DAT}$ and that the number of leaves reached maximum values of 108 leaves per plant at 90 DAT, showing a slight reduction until the end the evaluation period of the experiment. This reduction is probably associated with some physiological manifestation characteristic of the leaf senescence period (MUNIZ et al., 2014; 2015). In view of the results presented, it is possible to infer that, even in the conditions of climate and water quality available in the interior of Paraíba, fisális plants can reach up to 1.5 meters, as reported by Lopez Acosta et al. (2008) and Fischer, Almanza-Merchán and Miranda (2014).

According to Table 3 , at 55 DAT the estimated number of leaves reached values of up to $0.27 \mathrm{~m}^{2}$, values relatively higher than that mentioned by Muniz et al. (2014), in which the leaves measure 5 to $15 \mathrm{~cm}$ long and 4 to $10 \mathrm{~cm}$ wide. Kerbauy (2009) points out that plant leaves kept under shade have more stacked thylakoids, that is, a larger and more developed set of money than leaves grown under full sun, which justifies part of the results of the gas exchange assessment.

Although this crop is of indeterminate growth (RAMIREZ et al., 2013) and new leaves 
Tolerance to irrigation...

appear as it grows, leaf fall was observed after 30 DAT, plus the greater water requirement as intense flowering was an observed and significant increase in the number of leaves in all plants (Figure 3 ). This characteristic was more intense at different saline levels after 90 DAT, probably due to reduced growth and the end of the first crop cycle.

As highlighted by Rodrigues et al. (2013), the fisális cultivation in cold seasons (below $20^{\circ} \mathrm{C}$ ) can induce the plant to produce a greater number of leaves, influencing vegetative development, photosynthesis, and consequent accumulation of photoassimilates, favoring the later translocation to the reproductive phase of the plant. On the other hand, Tanan (2015) highlights that temperature above $30^{\circ} \mathrm{C}$ impairs fisális flowering and fruiting.

During the conduct of the experiment, the nutritional deficiency was observed in the form of yellowing or internerval chlorosis in old leaves at 20 DAT, due to the inhibition of magnesium $\left(\mathrm{Mg}^{2+}\right)$, whose element is mobile in plants and also acts in the plant cell's thylakoid (FREIRE et al., 2013;
SILVA, J. G. et al.

SIDDIQUI et al., 2018). This deficiency may have been a consequence of the $\mathrm{pH}$ of the soil, which was high (Table 2), requiring the application of sulfates in an attempt to acidify the soil and increase the availability of this nutrient for the plant.

Another morphological characteristic observed in the culture of fisális was the appearance of lateral branches throughout the plant, reaching an average of 22 branches by 120 DAT (Table 3 ). Although this is common in plants of indeterminate growth, Muniz et al. (2011) and Wanser et al. (2012) report that the number of side branches can influence productivity and number of leaves and, in some cases, must be eliminated, aiming at obtaining heavier fruits due to the increase of photoassimilates and accumulation of dry mass.

According to the analysis of variance regarding the parameters of the reproductive phase (Table 4), there was no significant effect $(\mathrm{p}>0.05)$ on the different salt levels in these phenological variables analyzed in fisális plants up to 120 DAT.

Table 4. Summary of analysis of variance for the number of flower buds (NFB), number of flowers (NFLOR), average fruit weight (AFW), polar diameter (PDF) and equatorial diameter (EDF), number of fruits per plant (NFPP) and productivity (PROD) in Physalis peruviana L. plants under different saline levels of irrigation water, under-protected environment conditions.

\begin{tabular}{|c|c|c|c|c|c|}
\hline & \multicolumn{5}{|c|}{--------- Medium square ----------- } \\
\hline & Salinity & Block & Mistake & Average & CV\% \\
\hline NFB & $124.016^{\mathrm{ns}}$ & $36.179^{\text {ns }}$ & 161.016 & 64 & 19.87 \\
\hline NFLOR & $66.551^{\mathrm{ns}}$ & $14.730^{\mathrm{ns}}$ & 227.241 & 63 & 23.96 \\
\hline NFPP & $49.879^{\mathrm{ns}}$ & $24.487^{\mathrm{ns}}$ & 166.402 & 63 & 20.61 \\
\hline$D P F$ & $0.755^{\mathrm{ns}}$ & $1.555^{\mathrm{ns}}$ & 2.343 & 13.05 & 11.73 \\
\hline$D E F$ & $1.751^{\mathrm{ns}}$ & $0.868^{\mathrm{ns}}$ & 2.397 & 12.68 & 12.21 \\
\hline$A F W$ & $0.016^{\mathrm{ns}}$ & $0.076^{\mathrm{ns}}$ & 0.160 & 1.78 & 22.51 \\
\hline PROD & $4.648^{\mathrm{ns}}$ & $3.761^{\mathrm{ns}}$ & 5.251 & 412778 & 17.55 \\
\hline DF & 3 & 4 & - & - & - \\
\hline
\end{tabular}

UFCG, Pombal, PB, June of 2020.

$\mathrm{ns}=$ not significant $(\mathrm{p}>0.05)$

The first manifestations related to the reproductive phase were characterized by the appearance of the first flower buds in the axilla of each node (Figure 4D) around 33 DAT. Then, the swelling of the floral bud was observed, beginning the pre-anthesis phase (Figure 4E), around 33 DAT, and anthesis at 36 DAT (Figure 4F). In this sense, Rodrigues et al. (2013) studying the phenological and productive characterization of $P$. peruviana $\mathrm{L}$. in the southern region of Minas Gerais observed the appearance of flower buds from the 27 DAT.
The flowering phase itself, characterized by the total opening of the yellow pentameric flowers, purple center, and green chalice (Figure 4G) occurred around 37 DAT. In post-anthesis, the sepals closed and later the fruit formation phase (Figure 4H), around 46 DAT, which followed its development (Figure 4I) and ripened at 65 DAT (Figure 4J), with maturation characterized by the yellow-brown color of the chalice. 


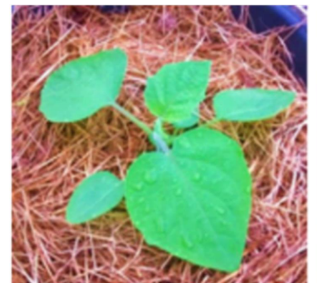

A

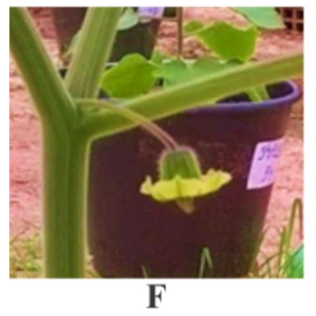

G

B
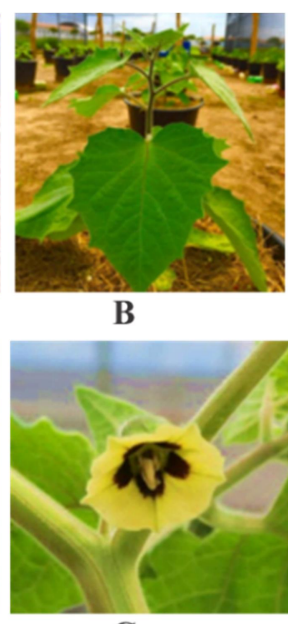

saline levels of irrigation water.

Seedling phase (A), vegetative stage from 25 to 32 DAT (B and C, respectively), flower bud at 33 DAT (D), pre-anthesis (5E), floral anthesis at 36 DAT (5F), immature fruits (H and I) and ripe fruit at 65 DAT (J). UFCG, Pombal, PB, June of 2020.

The difference observed between the average number of flower buds and flowers (Table 4) is a consequence of floral abortion, caused by a set of factors such as the absence of natural pollinators, reduced relative humidity, and elevated room temperature (Figure 1), the which, consequently, also affected the number of fruits per plant (NFPP) (Table 4). According to Silva et al. (2013), temperatures above $32{ }^{\circ} \mathrm{C}$ during flowering can cause floral abscission, pollen tube malformation, and egg aging. Souza, Alcântara Júnior, and Amorin (2007) used increasing values of $\mathrm{NaCl}\left(0.0 ; 4.0 ; 8.0 ; 12.0\right.$, and $\left.16.0 \mathrm{dS} \mathrm{m}^{-1}\right)$ in the hydroponic cultivation solution in $P$. angulata plants in the region of Feira de Santana - BA and obtained reduction in flowering and fruit production in plants grown under 4.0 and $8.0 \mathrm{dS} \mathrm{m}^{-1}$, due to the nutritional imbalance from these saline levels.

When evaluating the NFPP, it was found that, regardless of the treatment used, the average value was 63 fruits per plant. The number of main branches influenced the NFPP, with a reduction of $265.71 \%$ in relation to the 167 fruits obtained in $P$. angulata plants conducted in a free staking system, as observed by Tanan (2015) when evaluating the productivity of three Physalis species cultivated in the Semi-arid region of Bahia, obtaining variations between 2 and $12 \mathrm{~g}$ fruit $^{-1}$ and an average of 150 fruits per plant.

Regarding the polar (PD) and equatorial diameter (ED) of the fruits of fisális (Table 4), values of 13.05 and $12.68 \mathrm{~mm}$ were obtained, respectively. According to Silva et al. (2013), PD and ED, are important qualitative characteristics for the commercialization of fruits and are associated with the average fruit weight (AFW), suggesting that larger fruits will also be heavier and have a higher pulp content. Muniz et al. (2011) when carrying plants of fisális in a staking system of the spreader type, obtained fruits with ED of $13.65 \mathrm{~mm}$.

The PMF of fisális was, on average, $1.78 \mathrm{~g}$ per fruit (Table 4). The values observed here can be attributed to the nutritional management of the culture since Thomé and Osaki (2010) working with fisális obtained values of $1.15 \mathrm{~g}_{\text {fruit }}{ }^{-1}$ when they used increasing doses of $\mathrm{N}, \mathrm{P}, \mathrm{K}$ up to twice that recommended for tomato cultivation. While Tanan (2015) working with $P$. angulata in the semiarid region of Bahia obtained $2.5 \mathrm{~g}$ without using mineral fertilizer. According to Andriolo, Ross and Witter (2004) and Guimarães et al. (2009), the fruits are considered the main drain of the plant from the beginning of the fruiting until the last harvest of ripe fruits, reaching to accumulate more than $50 \%$ of the total dry mass-produced by the plant, which highlights the need for complementary fertilization soil fertility.

With regard to productivity, 412.778 fruits $\mathrm{ha}^{-1}$ were obtained, which is equivalent to $734.74 \mathrm{~kg}$ $\mathrm{ha}^{-1}$. The productivity in fisális plants seems to be more related to the plant's tolerance to climatic effects than to the effect of irrigation water salinity at levels up to $3.0 \mathrm{dS} \mathrm{m}^{-1}$. Taking into account the management adopted by Rodrigues et al. (2013) when evaluating the productivity in plants of fisális in the region of Lavras - MG, provided values of up to $955 \mathrm{~kg} \mathrm{ha}^{-1}$ with the direct influence of spacing $(1.5 \times 1.5 \mathrm{~m})$ and climatic factors in the production period (January to September 2011). Guedes et al. (2015) explain that under greenhouse conditions, the effect of saline levels can reduce plant productivity, spacing adopted in the cultivation area, the 
with the alternative use of water of different conductivities being recommended during the different phenological phases of the crop, as well as greenhouse conditions that provide the pollination by insects and the increase in the number of fruits per plant.

The data referring to the volume of water applied and drained per pot, as well as the ECd (Figure 5), in each of the treatments, suggest that, regardless of the treatments, the volume applied was the same, increasing as the plant developed a greater number of leaves (Figure 3B), leaf area (Table 3) and consequent transpiration, after $30 \mathrm{DAT}$, and started the reproductive phase, due to flowering and fruit formation (Figure 2). However, based on the volume drained, water consumption was higher for plants irrigated with $0.3 \mathrm{dS} \mathrm{m}^{-1}$ water (Figure 5A).

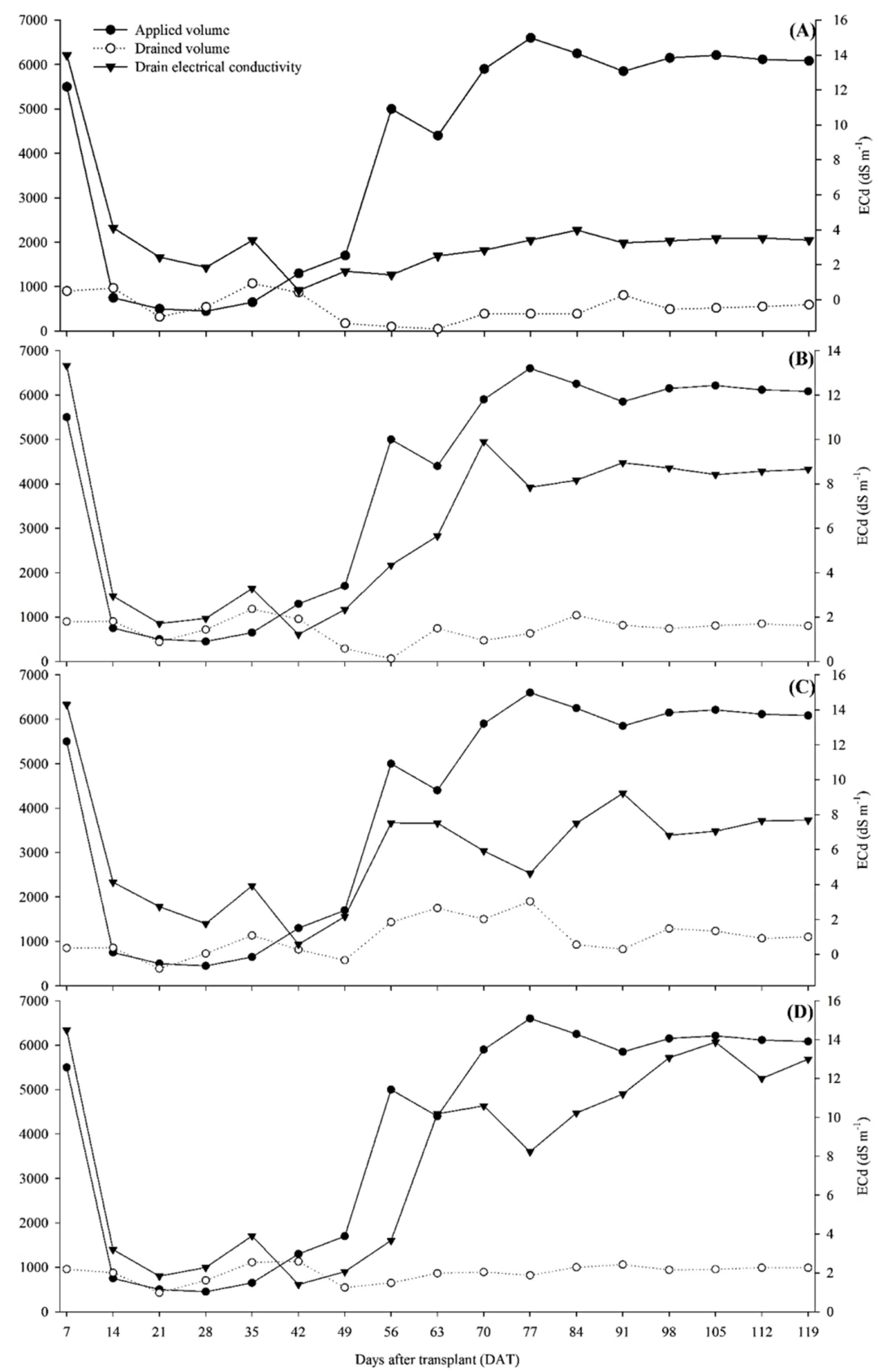

Figure 5. Volume of water applied (WA), drained (VD) and electrical conductivity of the drain (ECd) for saline levels 0.3 (A), 1.2 (B), 2.1 (C), and $3.0 \mathrm{dS} \mathrm{m}^{-1}$ (D) used in the irrigation of Physalis peruviana $\mathrm{L}$. under different saline levels of irrigation water, in a protected environment.

UFCG, Pombal, PB, June of 2020. 
The volume of rainfall represented in Figure 1 explains part of the results illustrated in Figure 5, because, in plants grown under saline stress, physiological drought can occur, in which, even with water in the soil, the plant cannot absorb due to the increase in osmotic potential $\left(\psi_{\mathrm{o}}\right)$ (AYERS; WESTCOT, 1991; RICHARDS, 1954). In addition to the possible increase in soil permeability, facilitating the removal of salts by leaching, culminating in an increase in ECd as there was a reduction in the volume of rainfall in the cultivation area after 70 DAT.

As reported by Guedes et al. (2015), the quality of the water used for irrigation is of fundamental importance in protected cultivation due to the need to wash the soil, so that the accumulation of salts does not occur. Therefore, the increase in ECd suggests an increase in the concentration of soluble salts and consequent effects on the plant. In this sense, it is possible to estimate $\psi o$ and electrical conductivity in the root zone $\left(\mathrm{EC}_{\mathrm{ZR}}\right)$ based on ECd (AYERS; WESTCOT, 1991).
Different from what Lima et al. (2009) mentions regarding the water requirement in plants of fisális under field conditions (2000 to $6000 \mathrm{~mL}$ plant $^{-1}$ day $^{-1}$ ), in this research, it was necessary to apply approximately $1000 \mathrm{~mL}$ plant $^{-1}$ day $^{-1}$. Corroborating the author's statement when he says that the type of soil and the cultivation environment as a whole must be taken into account.

The cultivation of fisális in rainfed conditions may become unfeasible due to the water requirement associated with the leaf area, thus increasing the crop's evapotranspiration. According to Santos and Carlesso (1998), the lower volume of water available in the soil for the plant can cause physiological damage, reduce the growth phases and induce the production of seeds (dissemination of the species), with the possibility of a loss of vigor and physiological quality of these.

At the end of the production cycle, characterized by a reduction in the number of flower buds and flowers on the plants, at 120 DAT the soil showed an increase in ECes and $\mathrm{pH}$ stability at different saline levels of irrigation water (Figure 6).

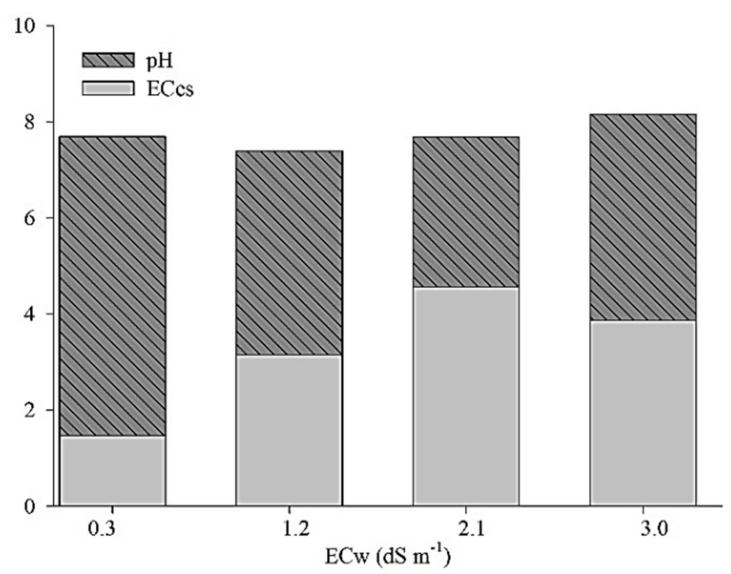

Figure 6. ECes $\left(\mathrm{dS} \mathrm{m} \mathrm{m}^{-1}\right)$ e $\mathrm{pH}$ of the soil for the different saline levels in the irrigation water used in the cultivation of Physalis peruviana L. in a protected environment at 120 DAT.

UFCG, Pombal, PB, June of 2020.

According to the Terminology Committee of the American Soil Science Society, soils with ECes above $4 \mathrm{dS} \mathrm{m}^{-1}$ and $\mathrm{pH}$ below 8.5 are considered to be saline, a fact observed only for the level of $2.1 \mathrm{dS} \mathrm{m}^{-1}$. The chemical composition of the soil and irrigation water used in this experiment (Table 1), as well as the ECd values (Figure 5), help to explain this behavior. In more, the addition of sulfated fertilizers in the initial cultivation phase proved to be effective in reducing the symptoms of nutritional deficiency in the leaf, however, it did not reduce the soil $\mathrm{pH}$ until 120 DAT.

This tolerance of fisális plants to the use of saline water up to 120 DAT, according to Souza,
Souza and Pelacani (2011) and Taiz et al. (2017), is divided into mechanisms that plants find to mitigate the effect of salts and accumulate ions in vacuoles and modify the metabolism of the plant, changing the stomatal and photosynthetic behavior and, consequently, the interruption of the xylemic flow, thus reducing the absorption of soluble salts.

Despite the mechanisms found by plants to mitigate the effects of salinity, certain visual aspects were observed in the form of bluish-green, thick, waxy, and yellowish leaves, possibly due to the accumulation of $\mathrm{Na}^{+}$from irrigation water (Table 1). As noted by Souza, Alcântara Júnior, and Amorim (2007), subdermalization of the hypodermis and 
Tolerance to irrigation...

endoderm can also occur with the formation of welldeveloped Caspari striae near the root apex, as highlighted by Dias and Blanco (2010).

\section{CONCLUSIONS}

Physalis peruviana L. fulfills its production cycle in approximately 115 DAT, with the vegetative phase comprising a period of 32 DAT and, from then on, the reproductive phase, which extended to $120 \mathrm{DAT}$. The fruit harvest started at 65 DAT, whose productivity under protected environment conditions was $734.74 \mathrm{~kg} \mathrm{ha}^{-1}$.

Plants of fisális were tolerant to saline levels of irrigation water of up to $3.0 \mathrm{dS} \mathrm{m} \mathrm{m}^{-1}$, without
SILVA, J. G. et al.

prejudice to the phenological characteristics of the culture. The unitary increase in salinity of irrigation water did not result in a significant effect on the physiological characteristics of fisális plants up to 60 DAT.

\section{ACKNOWLEDGMENTS}

Our thanks to the Ministry of Education for granting the scholarship for the agronomy tutorial education program (UFCG) for granting scholarships to the participants in this study.

The authors declare that there is no conflict of interest.

RESUMO: O cultivo de frutas não tradicionais tem ganhado espaço no setor de hortifrútis, mas que, em determinadas situações, são plantas que requerem estudos prévios relacionados a adaptabilidade de solo, clima e qualidade da água de irrigação. Neste sentido, este trabalho teve como objetivo avaliar os efeitos da salinidade da água de irrigação em plantas de Physalis peruviana L. (fisális) nas distintas fases de crescimento. A área experimental foi instalada nas dependências da Universidade Federal de Campina Grande, adotando o delineamento em blocos casualizados, com quatro níveis salinos da água de irrigação $\left(0,3 ; 1,2 ; 2,1\right.$ e 3,0 dS m $\left.{ }^{-1}\right)$ e cinco repetições por tratamento. As variáveis analisadas foram: diâmetro do caule, altura das plantas e número de folhas a cada 15 dias, área foliar aos 55 dias após o transplantio, número de ramos laterais, número de botões florais, número de flores, peso médio dos frutos, diâmetro polar e diâmetro equatorial dos frutos, número de frutos por planta e produtividade. Conforme os resultados, as plantas se mostraram tolerantes a níveis salinos da água de irrigação de até $3,0 \mathrm{dS} \mathrm{m}{ }^{-1}$, sem prejuízos nas características fenológicas da cultura e produtivas. $\mathrm{O}$ aumento unitário da salinidade da água de irrigação não resultou em danos nas características fisiológicas das plantas até os 60 dias de transplantio.

PALAVRAS-CHAVE: Condutividade elétrica. Physalis peruviana L. Produtividade. Semiárido.

\section{REFERENCES}

ANDRIOLO, J. L.; ROSS, T. D.; WITTER, M. Crescimento, desenvolvimento e produtividade do tomateiro cultivado em substrato com três concentrações de nitrogênio na solução nutritiva. Ciência Rural, Santa Maria, v.34, p.1451-1457, 2004. https://doi.org/10.1590/S0103-84782004000500019

AYERS, R. S.; WESTCOT, D. W. A qualidade da água na agricultura. Campina Grande: UFPB, 1991. $218 \mathrm{p}$.

BARROSO, N. S. Maturação de frutos e viabilidade de sementes de Physalis ixocarpa Brot. Ex Hormen. 2015. 39 f. Dissertação (Mestrado) - Recursos Genéticos Vegetais, Departamento de Recursos Genéticos Vegetais, Universidade Estadual de Feira de Santana - BA, UEFS, 2015, Cap. 1.

CAMPOS, V. B.; CAVALCANTE, L. F. Salinidade da água e biofertilizante bovino: Efeito sobre a biometria do Pimentão. Holos, Mossoró, v.2, n.25, p.10-20, 2009. https://doi.org/10.15628/holos.2009.233

DIAS, N. S.; BLANCO, F.F. Efeitos dos sais no solo e na planta. In: GHEYI, H. R.; DIAS, N. S.; LACERDA, C. F de (Ed). Manejo da salinidade na agricultura: estudos básicos e aplicados. Fortaleza: INCTSal, 2010. p. 129-141. 
EMBRAPA - Empresa Brasileira de Pesquisa Agropecuária. Centro Nacional de Pesquisa de Solos. Sistema Brasileiro de Classificação de Solos. $5^{\mathrm{a}}$.ed. Brasília, 2018, 590p.

FERREIRA, D. F. Sisvar - software: versão 5.3. Lavras: UFLA/DEX, 2011. Software.

FILGUEIRA, F. A. R. Solanáceas: Agrotecnologia moderna na produção de tomate, batata, pimentão, pimenta, beringela e jiló. Lavras - MG: UFLA, 2003. 328 p.

FISCHER, G.; ALMANZA-MERCHÁN, P. J.; MIRANDA, D. Importancia y cultivo de la uchuva (Physalis peruviana L.). Revista Brasileira de Fruticultura, Jaboticabal, v.36, n.1, p.1-15, 2014.

https://doi.org/10.1590/0100-2945-441/13

FREIRE, J. L. O.; CAVALCANTE, L. F.; NASCIMENTO, R.; REBEQUI, A. M. Teores de clorofila e composição mineral foliar do maracujazeiro irrigado com águas salinas e biofertilizante. Revista de Ciências Agrárias, Lisboa, v.36, n.1, p.57-70, 2013.

GUEDES, R. A. A.; OLIVEIRA, F. A.; ALVES, R. C.; MEDEIROS, A.; GOMES, L. P.; COSTA, L. P. Estratégias de irrigação com água salina no tomateiro cereja em ambiente protegido. Revista Brasileira de Engenharia Agrícola e Ambiental, v.19, n.10, p.913-919, 2015. http://dx.doi.org/10.1590/18071929/agriambi.v19n10p913-919

GUIMARÃES, M. A.; SILVA. D. J. H.; PETERNELLI, L. A.; FONTES. P. C. R. Distribuição de fotoassimilados em tomateiro com e sem a retirada do primeiro cacho. Bioscience Journal, Uberlândia, v.25, n.5, p.83-92, 2009.

IANCKIEVICZ, A.; TAKAHASHI, H. W.; FREGONEZI, G. A. F.; RODINI, F. K. Produção e desenvolvimento da cultura de Physalis L. submetida a diferentes níveis de condutividade elétrica da solução nutritiva. Ciência Rural, Santa Maria, v.43, n.3, p.438-444, 2013. https://doi.org/10.1590/S010384782013000300010

KERBAUY, G. B. Fisiologia vegetal, $2^{\mathrm{a}}$ ed., Rio de Janeiro, Guanabara Koogan, 2009, 431p.

LIMA, C. S. M.; MANICA-BERTO, R.; SILVA, S. J. P.; BETEMPS, D. L.; RUFATO, A. R. Custos de implantação e condução de pomares de Physalis na região sul do estado do Rio Grande do Sul. Revista Ceres, Viçosa, v.56, n.5, p.555-561, 2009.

LIMA, L. A.; OLIVEIRA, F. A.; ALVES, R. C.; LINHARES, P. S. F.; MEDEIROS, A. M. A.; BEZERRA, F. M. S. Tolerância da berinjela à salinidade da água de irrigação. Revista agro@mbiente, Boa vista, v.9, n.1, p.27-34, 2015. https://doi.org/10.5327/Z1982-8470201500012202

LOPEZ ACOSTA, F. J.; TENJO, N.R. G.; FISHER, G.; LASPRILLA, D. M. Propagación de uchuva (Physalis peruviana L.) mediante diferentes tipos de esquejes y substratos. Revista Facultad Nacional de Agronomía, Medellín, v.61, p.4347-4357, 2008.

MUNIZ, J.; KRETZSCHMAR, A. A.; RUFATO, L.; PELIZZA, T. R.; MARCHI, T.; DUARTE, A. E.; LIMA, A. P. F.; GARANHANI, F. Sistemas de condução para o cultivo de Physalis no planalto catarinense. Revista Brasileira de Fruticultura, Jaboticabal, v.33, n.3, p.830-838, 2011. https://doi.org/10.1590/S010029452011005000083

MUNIZ, J.; KRETZSCHMAR, A. A.; RUFATO, L. PELIZZA, T. R.; RUFATO, A. R.; MACEDO, T. A. General aspects of physalis cultivation. Ciência Rural, Santa Maria, v.44, n.6, p.964-970, 2014. https://doi.org/10.1590/S0103-84782014005000006 
MUNIZ, J.; MARCHI, T.; COLDEBELLA, M. C.; RUFATO, L. KRETZSCHMAR, A. A. Crescimento vegetativo e potencial produtivo de fisális. Revista de Ciências Agroveterinárias, Lages, v.14, n.1, p.15-23, 2015.

PUENTE, L. A.; PINTO-MUNOZ, C. A.; CASTRO, E. S.; CORTÉS, M. Physalis peruviana Linnaeus, the multiple properties of highly functional fruit: A review. Food Research International, Canadá, v.44, n.1, p.1733-1740, 2011. https://doi.org/10.1016/j.foodres.2010.09.034

RAMÍREZ, L.; FISCHER, G.; DAVENPORT, T. L.; PINZÓN, J. C. A.; ULRICHS, C. Cape gooseberry (Physalis peruviana L.) phenology according to the BBCH phenological scale. Scientia Horticulturae, [s.1], v.162, p.39-42, 2013. https://doi.org/10.1016/j.scienta.2013.07.033

REIS, L. S.; AZEVEDO, C. A. V.; ALBUQUERQUE, A. W.; SOUZA JÚNIOR, J. F. Índice de área foliar e produtividade do tomate sob condições de ambiente protegido. Revista Brasileira de Engenharia Agrícola e Ambiental, Campina Grande, v.17, n.4, p.386-391, 2013. https://doi.org/10.1590/S1415-43662013000400005

RICHARDS, L. A. Diagnosis and improvement of saline and alkali soils. Washington: USDA (USDA Agriculture Handbook, 60), 160 p. 1954.

RODRIGUES, F. A.; PENONI, E. S.; SOARES, J. D. R.; SILVA, R. A. L.; PASQUAL, M. Caracterização fenológica e produtividade de Physalis peruviana cultivada em casa de vegetação. Bioscience Journal, Uberlândia, v.29, n.6, p.1771-1777, 2013.

SANTOS, R. F.; CARLESSO, R. Déficit hídrico e os processos morfológicos e fisiológico das plantas. Revista Brasileira de Engenharia Agrícola e Ambiental, Campina Grande, v.2, n.3, p.287-294, 1998.

https://doi.org/10.1590/1807-1929/agriambi.v2n3p287-294

SIDDIQUI, M. H.; ALAMRI, S. A.; AL-KHAISHANY, M. Y.; AL-QUTAMI, M. A.; ALI, H. M.; ALWHAIBI, M. H.; AL-WAHIBI, M. S.; ALHARBY, H. F. Mitigation of adverse effects of heat stress on Vicia faba by exogenous application of magnesium. Saudi Journal of Biological Sciences, Arábia Saudita, v.25, n.7, p.1393-1401, 2018. https://doi.org/10.1016/j.sjbs.2016.09.022

SILVA, V. P. R.; PEREIRA, E.R.R.; AZEVEDO, P.V.; SOUSA, F.A.S.; SOUSA, I.F. Análise da pluviometria e dias chuvosos na região Nordeste do Brasil. Revista Brasileira de Engenharia Agrícola e Ambiental, Campina Grande, v.15, n.2, p.131-138, 2011. https://doi.org/10.1590/S1415-43662011000200004

SILVA, J. M.; FERREIRA, R. S.; MELO, A. S.; SUASSUNA, J. F.; DUTRA, A. F.; GOMES, J.P. Cultivo de tomateiro em ambiente protegido sob diferentes taxas de reposição da evapotranspiração. Revista Brasileira de Engenharia Agrícola e Ambiental, Campina Grande, v.17, n.1, p.40-46, 2013. https://doi.org/10.1590/S141543662013000100006

SILVA, F. G.; DUTRA, W. F.; DUTRA, A. F.; OLIVEIRA, I. M.; FILGUEIRAS, L. M. B.; MELO, A. S. Trocas gasosas e fluorescência da clorofila em plantas de berinjela sob lâminas de irrigação. Revista Brasileira de Engenharia Agrícola e Ambiental, Campina Grande, v.19, n.10, p.946-952, 2015. http://dx.doi.org/10.1590/1807-1929/agriambi.v19n10p946-952

SOUZA, N. K. R.; ALCÂNTARA JÚNIOR, P. P.; AMORIM, S. M. C. Efeito do estresse salino sobre a produção de fitomassa em Physalis angulata L. (Solanaceae). Revista acadêmica, Curitiba, v.5, n.4, p.379384, 2007. http://dx.doi.org/10.7213/cienciaanimal.v5i4.10184

SOUZA, M. O.; SOUZA, C. L. M.; PELACANI, C. R. Germinação de sementes osmocondicionadas e não osmocondicionadas e crescimento inicial de Physalis angulata L. (Solanaceae) em ambientes salinos. Acta Botânica Brasílica, Brasília, v.25, n.1, p.105-112, 2011. https://doi.org/10.1590/S0102-33062011000100013 
TAIZ, L.; ZEIGER, E.; MØLLER, I. M.; MURPHY, A. Fisiologia vegetal. (6ed.). 888p. Porto Alegre, Artmed, 2017.

TANAN, T. T. Fenologia e caracterização dos frutos de espécies de Physalis cultivadas no semiárido Baiano. 2015. 58 f. Dissertação (Mestrado) - Recursos Genéticos Vegetais, Departamento de Recursos Genéticos Vegetais, Universidade Estadual de Feira de Santana - BA, UEFS, 2015, Cap. 2.

THOMÉ, M.; OSAKI, F. Adubação de nitrogênio, fósforo e potássio no rendimento de Physalis spp. Ciências Agrárias e Ambientais, Curitiba, v.8, n.1, p.11-18, 2010. http://dx.doi.org/10.7213/cienciaanimal.v8i1.10364

VASCONCELOS, S. S.; FEARNSIDE, P.M.; GRAÇA, P. M. L. A.; SILVA, P.R. T.; DIAS, D. V.

Suscetibilidade da vegetação ao fogo no sul do amazonas sob condições meteorológicas atípicas durante a seca de 2005. Revista Brasileira de Meteorologia, São José dos Campos, v.30, n.2, p.134-144, 2015.

https://doi.org/10.1590/0102-778620140070

WANSER, A. F.; MUELLER, S.; SUZUKI, A.; BECKER, W. F.; SANTOS, J. P. Produtividade de híbridos de tomate submetidos ao cultivo superadensado. Horticultura Brasileira, Recife, v.30, n.1, p.168-174, 2012.

https://doi.org/10.1590/S0102-05362012000100028 